\title{
The Relationship between EFL Learners' Language Learning Strategy Use and Achievement
}

\author{
Özgül Balc1 ${ }^{1} \&$ Selma Durak Üğ̈̈ten ${ }^{1}$ \\ ${ }^{1}$ School of Foreign Languages, Necmettin Erbakan University, Konya, Turkey \\ Correspondence: Özgül Balc1, Necmettin Erbakan University, School of Foreign Languages, Meram Campus, \\ 42090 Meram, Konya, Turkey. Tel: 90-332-323-8220/5771. E-mail: obalci@konya.edu.tr
}

Received: May xx, 2017

Accepted: July 9, 2017 Online Published: January 26, 2018

doi:10.5539/ies.v11n2p1

URL: https://doi.org/10.5539/ies.v11n2p1

\begin{abstract}
The primary purpose of this study was to examine the relationship between language learning strategy use and foreign language achievement, focusing on differences in gender. A total of 263 English as a foreign language students enrolled in English preparatory class program at Necmettin Erbakan University, School of Foreign Languages participated in the study. This was a descriptive study in relational screening model. The Turkish version of "Strategy Inventory of Language Learning (SILL)", originally developed by Oxford (1990) and adapted into Turkish by Cesur and Fer (2007), was used as the data collection tool. Results from the study indicated that metacognitive strategies were the most frequently used strategies among the participants, while cognitive strategies were the least frequently used. There was no significant difference between the male and female students in terms of language learning strategy use except memory strategies. Also, low but statistically significant positive correlations were observed between foreign language achievement and cognitive $(\mathrm{r}=0.23$; $\mathrm{p}=0.00)$, compensation $(\mathrm{r}=0.16 ; \mathrm{p}=0.01)$ and metacognitive strategies $(\mathrm{r}=0.15 ; \mathrm{p}=0.02)$. The findings reported in the study suggest that high-level strategy use could affect students' achievement in foreign language preparatory classes.
\end{abstract}

Keywords: language learning strategies, strategy use, achievement, foreign language teaching

\section{Introduction}

Language learning strategy research has attracted increasing attention since Rubin's (1975) original article suggesting that the strategies of good language learners could help teachers improve their less successful students' second/foreign language (L2) competence. Strategies successful language learners use has been subject to several studies (Bruen, 2001; Chamot \& El-Dinary, 1999; Chamot \& Kupper, 1989; Green \& Oxford, 1995; Kunasaraphan, 2015; Park, 2010; Qingquan, Chatupote, \& Teo, 2008) since then to contribute to language proficiency enhancement in English as a second language (ESL) and English as a foreign language (EFL) context. In strategy literature, many studies have reported positive associations between language learning strategy use and language performance (Chang \& Liu, 2013; Ghavamnia, Kassaian, \& Dabaghi, 2011; Green \& Oxford, 1995; Hong-Nam \& Leavell, 2006; Magogwe \& Oliver, 2007; Tam, 2013).

Griffiths et al. (2014) emphasize that language learning strategies can create "more engaged, more effective" (p. 62) learning environment. The authors further point out that strategy instruction, assessment, and research are very important in terms of effective language learning. Griffiths (2003) reflects that "the possibility that effective use of language learning strategies might contribute to successful language learning is exciting" (p. 381). Also, Griffiths and Oxford (2014, p. 7) assert that in spite of the problems regarding language learning strategy field, language learning strategies facilitate language learning and the literature on language learning strategies provides important information for teachers, learners, and researchers. Oxford and Burry-Stock (1995) point out that replication of studies is necessary to increase consistent information on language learning strategy use by students from different countries and cultures. Moreover, Fewell (2010) indicates that studies investigating language learners in an EFL environment are quite rare when compared to available ESL research. Starting from this point of view, this study attempts to investigate the university preparatory class students' language learning strategy use and the relationship between language learning strategy use and foreign language learning achievement. It is expected that findings from the current study will contribute to language learning, language teaching, and strategy research. 


\section{Review of Literature}

Characteristics of good language learners have provided the inspiration for several studies on language learning strategies since the 1970s. Chamot and Kupper (1989) explicitly mention that effective language learners can choose and use language learning strategies to reach their goals. In the early work by Rubin $(1975$, p. 43), language learning strategies are defined as "techniques or devices which a learner may use to acquire knowledge". Chamot and Kupper (1989) define language learning strategies as "techniques which students use to comprehend, store, and remember new information and skills" (p. 246). Green and Oxford (1995) offer another similar definition of language learning strategies as being "specific actions or techniques that students use, often intentionally, to improve their progress in developing L2 skills" (p. 262).

Oxford (1990, p. 9) lists the features of language learning strategies. According to the author, language learning strategies:

- encourage the development of communicative competence.

- encourage learner self-direction.

- create new roles for teachers.

- $\quad$ are used to solve a problem.

- $\quad$ are specific actions or behaviors taken by students to enhance learning.

- include many aspects of the learner such as metacognitive, affective and social in addition to cognitive functions.

- contribute directly and indirectly to learning.

- $\quad$ are sometimes hard to observe.

- are often conscious efforts by learners to take control of learning.

- $\quad$ are easy to teach and modify.

- $\quad$ are flexible.

- $\quad$ are affected by many factors such as age, learning style, stage of learning.

Although many attempts have been made, the literature is far from reaching a consensus on the classification of language learning strategies. Rubin (1981) developed one of the early taxonomies of language learning strategies. The researcher classifies language learning strategies into two main categories as strategies that directly contribute to language learning (clarification/verification, monitoring, memorization, guessing/inductive inferencing, deductive reasoning and practice) and strategies that contribute indirectly to language learning process (creating opportunities for practice and production tricks). In the study by Chamot and Kupper (1989), language learning strategies were classified in three general categories: metacognitive, cognitive, social and affective strategies. The authors identify metacognitive strategies as the "self-regulatory strategies" (p. 14) and explain that these strategies are used for planning, monitoring and evaluating learners' own learning efforts; cognitive strategies are used to cope with language tasks, while social and affective strategies are used to maintain social interaction in the learning process when needed. Naiman, Frohlich, Stern, and Todeco proposed an alternative classification of five broad categories of learning strategies which are an active task approach, realization of a language as a system, realization of language as a means of communication and interaction, management of affective domains, and monitoring of second language performance (as cited in Chamot, O'Malley, Kupper, \& Impink-Hernandez, 1987, p. 18). More recently Hsiao and Oxford (2002) compared different classification theories of language learning and found that Oxford's well-known language learning strategy taxonomy (metacognitive, cognitive, memory, compensation, social, and affective) "is the most consistent with learners' strategy use" (p. 368). Oxford (1990) divided language learning strategies into two major categories, direct and indirect strategies which are also subdivided into six groups. Direct strategies which are used to deal with the target language include memory strategies for storing and retrieving the new information, cognitive strategies for understanding and producing the new language and compensation strategies for using the language despite limited knowledge. Indirect strategies which are used to manage the learning process include metacognitive strategies for controlling language learning process, affective strategies for controlling feelings, attitudes and emotions and also social strategies for facilitating interaction with other people in the learning process.

Language learning strategies are the factors essential during course planning and teaching practice and vital for classroom learning (Oxford and Burry-Stock, 1995). On the other hand, language learning strategies help 
students take responsibility for improving their own learning (Green and Oxford, 1995). It is evident in literature that appropriate use of language learning strategies helps learners improve their proficiency and increase self-confidence (Oxford, 1990). Because as Chamot (2004) indicates strategic learners have metacognitive knowledge about their own learning process and are skilled in using strategies compatible with the task and their learning strengths. Also, Fewell (2010) indicates that noticeable similarities of patterns in the utilization of language learning strategies shared by high proficiency learners and the noted distinctions shared by low proficiency learners demonstrate the importance of language learning strategies as an influential variable related in some degree to eventual success or failure in language learning. In a nutshell, it is reported that effective language learning can be enhanced through effective use of strategies (Chamot and Kupper, 1989).

When the literature is reviewed, it becomes apparent that many factors affect the use of language learning strategy use. Rubin (1975) lists several strategies successful language learners employ but also emphasizes that use of language learning strategies would vary in terms of some factors such as the task, learning stage, age, context, individual styles, and cultural differences in cognitive learning styles. As one of the leading researchers in the field, Oxford (1990) also lists many factors affecting strategy use including degree of awareness, stage of learning, task requirements, teacher expectations, age, gender, nationality, general learning style, personality traits, motivation level, and purpose for learning the language.

The relationship of gender and proficiency with language learning strategy use has been subject to many studies in L2 literature. In several studies gender has been suggested as one of the factors influencing language learning strategy use (Božinovic \& Sindik, 2011; El-Dib, 2004; Goh \& Foong, 1997; Oxford \& Nyikos, 1989; Seffar, 2014). However, there have been studies which have revealed that language learning strategy use is not affected by gender (Griffiths, 2003; El-Dib, 1999 as cited in El-Dib, 2004, p. 93).

Many studies have revealed that proficiency has a significant positive relationship with language learning strategy use (Altan, 2003; Bruen, 2001; El-Dib, 2004; Ghavamnia et al., 2011; Goh \& Foong, 1997; Kunasaraphan, 2015; Oxford \& Nyikos, 1989). For example, Hong-Nam and Leavell (2006) investigated the relationship between language learning strategy use and second language proficiency of ESL students. In their study, intermediate level students reported more use of learning strategies than beginning and advanced levels. Bruen (2001) reported that a high level of strategy use was associated with higher levels of proficiency in German as a foreign language. In a study by Magogwe and Oliver (2007) it was found that there was a significant effect of proficiency on primary school students' strategy use. So, it could be concurred that successful language learners use more language learning strategies and more appropriately (Bruen, 2001; Chamot and Kupper, 1989; Green and Oxford, 1995; Park, 2010). Oxford (1989) clearly mentions that more proficient learners use more strategies in different situations when compared to less proficient learners, but also points out that the relationship between strategy use and performance is also complex. Along these lines, Chamot and Kupper (1989) remark that effective language learners use various language learning strategies appropriately, while less effective students use strategies less frequently and less appropriately and their repertoire of strategies is limited.

El-Dib (2004) explains that we are still far from generalizing regarding the relationship between language learning strategies and a considerable number of variables such as gender, proficiency, learning style because of the contradictory findings and limited number of replication studies. The researcher suggests that "calls continue to be made for more studies in these areas to ascertain these findings and resolve the discrepancies". As an attempt to respond to the call by El-Dib (2004) and given the research discussed above the present study explores the language learning strategy use of EFL students enrolled in English preparatory class program at university and the relationship between language learning strategy use and foreign language achievement focusing on gender differences. Based on the foregoing research, the present study was designed to address the following research questions specifically:

1) What are the most and least frequently used language learning strategies by English preparatory class EFL learners?

2) Does students' frequency of language learning strategy use and foreign language achievement differ significantly by gender?

3) Is there a relationship between learners' language learning strategy use and foreign language achievement?

\section{Methodology}

\subsection{Design of the Study}

The present study, which mainly aims to investigate the relationship between language learning strategy use and 
foreign language achievement, is a descriptive study in relational screening model. Relational screening model aims to determine the existence and level of covariance between two or more variables (Karasar, 2005).

\subsection{Participants}

A total of 263 EFL students (125 female and 138 male) attending the English preparatory class program at Necmettin Erbakan University, School of Foreign Languages in Konya, Turkey participated in this study (see Table 1). These were all volunteer students enrolled in different departments (see Table 2) at Necmettin Erbakan University. Many of the participants were enrolled in the departments offered by the university such as civil aviation management, international relations, aircraft engineering, industrial engineering, mechatronics engineering and energy systems engineering. Other participants consisted of students enrolled in different departments of Faculty of Engineering and Architecture, Faculty of Social Sciences and Humanities, Faculty of Tourism.

Table 1. Number of participants by gender

\begin{tabular}{lcccc}
\hline & Frequency & Percent & Valid Percent & Cumulative Percent \\
\hline Female & 125 & 47.5 & 47.5 & 47.5 \\
Male & 138 & 52.5 & 52.5 & 100 \\
Total & 263 & 100 & 100 & \\
\hline
\end{tabular}

Table 2. Number of participants by fields of study

\begin{tabular}{lcccc}
\hline & Frequency & Percent & Valid Percent & Cumulative Percent \\
\hline Civil aviation management & 64 & 24 & 24 & 24 \\
International relations & 60 & 23 & 23 & 47 \\
Aircraft engineering & 37 & 14 & 14 & 61 \\
Industrial engineering & 30 & 11 & 11 & 73 \\
Mechatronics engineering & 8 & 03 & 03 & 76 \\
Energy systems engineering & 6 & 02 & 02 & 78 \\
Other (17 different fields of study) & 58 & 22 & 22 & 100 \\
Total & 263 & 100 & 100 & \\
\hline
\end{tabular}

\subsection{Instrumentation and Procedure}

Questionnaires are thought to be the most frequent and efficient method to identify language learners' strategies despite the limitations (Chamot, 2004). Students' language learning strategies were measured by the Turkish version of "Strategy Inventory of Language Learning (SILL)", originally developed by Oxford (1990) and adapted into Turkish by Cesur and Fer (2007). Also, Oxford and Burry-Stock (1995) emphasize that its reliability across many cultural groups is high. SILL is a self-report questionnaire based on Oxford's (1990) language learning strategy classification and used to determine how often each group of language learning strategies is used by EFL learners. Cesur and Fer (2007) reported that Cronbach's alpha reliability coefficient for the total scale was 0.92 and for the subscales ranged from 0.59 to 0.86 . Internal consistency for the present sample was as follows:

Strategy

Memory strategies

Cognitive strategies

Compensation strategies

Metacognitive strategies

Affective strategies

Social strategies

Total scale
Cronbach's Alpha

0.83

0.59

0.88

0.58

0.67

0.93

\subsection{Data Collection and Analysis}

Data were collected during the class period and it took approximately 15-20 minutes to complete. Students were informed that their participation in the study was completely voluntary and confidential, and would have no 
bearing on their grades. Department of Basic Foreign Languages of the participating school approved the study. Also, students' end-of-the-year scores were used as the achievement measure.

The data were tested for normal distribution with the Kolmogorov-Smirnov test and for homogeneity of variances with Levene's test. Students' language learning strategies were analyzed by descriptive statistics (mean, frequency, percentage and standard deviation). Unpaired t-tests were used to compare mean values between females and males. The Pearson's correlation coefficient was used to determine the relationship between achievement and language learning strategies with the SPSS 16.0 for Windows statistical package. Statistical significance was set at a $\mathrm{p}<0.05$ level.

\subsection{Assumptions and Limitations}

Several limitations in this study need to be considered while evaluating its findings. First, students' language learning strategies were identified through questionnaires which are a type of self-report method. As Chamot (2004) indicates, questionnaires could have some limitations in that students may not remember which strategies they have used before, may claim that they have used strategies which they have not used, or may not understand exactly some of the items in the questionnaire. So, as the SILL is a self-report questionnaire, it is assumed that the students answered the questions honestly and accurately. The second limitation is the number of the participants, which was limited to 263 preparatory class students at Necmettin Erbakan University, School of Foreign Languages. Generalizability of the study may be limited given that the study was conducted in only one university and only with Turkish students. Furthermore, other factors such as the school environment, assessment methods during the year, the role of the teachers and foreign language environment the students were in should be considered while generalizing the results of the present study.

\section{Results}

The research results are presented below according to the hypothesis previously stated.

Table 3. Descriptive statistics of participants' language learning strategy use

\begin{tabular}{lcccc}
\hline Strategies & Frequency & Percent & Valid Percent & Cumulative Percent \\
\hline Memory & 28.0 & 10.6 & 10.6 & 10.6 \\
Cognitive & 11.0 & 4.2 & 4.2 & 14.8 \\
Compensation & 71.0 & 27.0 & 27.0 & 41.8 \\
Metacognitive & 85.0 & 32.3 & 32.3 & 74.1 \\
Affective & 13.0 & 4.9 & 4.9 & 79.1 \\
Social & 55.0 & 20.9 & 20.9 & 100.0 \\
Total & 263.0 & 100.0 & 100.0 & \\
\hline
\end{tabular}

As it is clear in Table 3, metacognitive strategies (32.3\%) were the most frequently used strategies among students participating in the study, followed by compensation $(27.0 \%)$, social $(20.9 \%)$, memory (10.6\%), affective $(4.9 \%)$ and cognitive $(4.2 \%)$ strategies respectively.

Table 4. Participants' language learning strategy use by gender

\begin{tabular}{|c|c|c|c|c|c|c|c|c|c|c|}
\hline & \multicolumn{3}{|c|}{ Male } & \multicolumn{3}{|c|}{ Female } & \multirow[b]{2}{*}{$\mathrm{p}$} & \multicolumn{3}{|c|}{ Total } \\
\hline & Mean & \pm & SD & Mean & \pm & SD & & Mean & \pm & SD \\
\hline Memory & 3.0 & \pm & 0.7 & 3.2 & \pm & 0.6 & 0.00 & 3.1 & \pm & 0.6 \\
\hline Cognitive & 3.0 & \pm & 0.6 & 3.1 & \pm & 0.6 & 0.34 & 3.1 & \pm & 0.6 \\
\hline Compensation & 3.3 & \pm & 0.6 & 3.3 & \pm & 0.7 & 0.79 & 3.3 & \pm & 0.6 \\
\hline Metacognitive & 3.4 & \pm & 0.7 & 3.5 & \pm & 0.8 & 0.07 & 3.4 & \pm & 0.8 \\
\hline Affective & 2.8 & \pm & 0.6 & 2.9 & \pm & 0.7 & 0.22 & 2.8 & \pm & 0.6 \\
\hline Social & 3.4 & \pm & 0.6 & 3.3 & \pm & 0.7 & 0.56 & 3.4 & \pm & 0.7 \\
\hline
\end{tabular}

As Table 4 shows, the mean scores of the female were higher than those of the male students. However, the independent t-test did not yield any significant difference between the mean scores of the male and those of the female students except memory strategies $(p>0.05)$. In terms of memory strategies, a statistically significant difference was found between the male and female students in favor of the female students $(p<0.05)$. 
Table 5. Comparison of achievement and total language learning strategy use by gender

\begin{tabular}{|c|c|c|c|c|c|c|c|c|c|c|}
\hline & \multicolumn{3}{|c|}{ Male } & \multicolumn{3}{|c|}{ Female } & \multirow[b]{2}{*}{$\mathrm{p}$} & \multicolumn{3}{|c|}{ Total } \\
\hline & Mean & \pm & SD & Mean & \pm & SD & & Mean & \pm & SD \\
\hline Achievement & 73.8 & \pm & 10.9 & 75.8 & \pm & 9.4 & 0.25 & 74.5 & \pm & 10.2 \\
\hline Language learning strategy use & 3.1 & \pm & 0.5 & 3.2 & \pm & 0.5 & 0.15 & 3.2 & \pm & 0.5 \\
\hline
\end{tabular}

As Table 5 indicates, there was no significant difference in the achievement and total language learning strategy use mean scores of the male and female students ( $p>0.05)$. Also it is clear that both the male and female students had medium level language learning strategy use according to Oxford's $(1990, p .300)$ classification of strategy use.

Table 6. Correlation coefficient between language learning strategies and achievement

\begin{tabular}{lcc}
\hline & \multicolumn{2}{c}{ Achievement } \\
\cline { 2 - 3 } Strategies & $\mathrm{r}$ & $\mathrm{p}$ \\
\hline Memory & 0.02 & 0.75 \\
Cognitive & 0.23 & 0.00 \\
Compensation & 0.16 & 0.01 \\
Metacognitive & 0.15 & 0.02 \\
Affective & 0.03 & 0.67 \\
Social & 0.11 & 0.08 \\
Total & 0.16 & 0.01 \\
\hline
\end{tabular}

Low but statistically significant positive correlations were found between students' achievement scores and the use of cognitive $(r=0.23 ; \mathrm{p}=0.00)$, compensation $(\mathrm{r}=0.16 ; \mathrm{p}=0.01)$ and metacognitive $(\mathrm{r}=0.15 ; \mathrm{p}=0.02)$ strategies. Also, a low but statistically significant positive correlation was observed between total strategy use and achievement $(\mathrm{r}=0.16 ; \mathrm{p}=0.01)$.

\section{Discussion}

The primary purpose of this study was to investigate the relationship between foreign language achievement and the use of language learning strategies. The results of Pearson's correlation analysis revealed that foreign language achievement had a low but significant positive correlation with total language learning strategy use. This finding is in line with those of previous studies which have reported positive relationships between performance in language learning and the use of language learning strategies (Al-Qahtani, 2013, Altan, 2003; Bruen, 2001; Ghavamnia et al., 2011; Goh \& Foong, 1997; Green \& Oxford, 1995; Griffiths, 2003; Kaylani, 1996; Magogwe \& Oliver, 2007; Park, 2010; Tam, 2013). In a similar way O'Malley, Chamot, and Kupper (1987) found that effective L2 learners used language learning strategies more often than ineffective learners. Chamot and Kupper (1989) discovered that more successful learners used more language learning strategies, more frequently and more appropriately while less successful learners used less language learning strategies, less frequently and less appropriately. Chamot and El-Dinary (1999) reported some differences in the types of strategies more effective and less effective students relied on when reading. Bruen (2001) found that more proficient students used more language learning strategies especially more cognitive and metacognitive strategies and in a more frequent way. Altan (2003) revealed that the relationship between language learning strategies and foreign language achievement was linear. Griffiths (2003) concluded that higher level students made highly frequent use of a large number of language learning strategies relating to interaction with others, to vocabulary, to reading, to the tolerance of ambiguity, to language systems, to the management of feelings, to the management of learning, and to the utilization of available resources. The author emphasized that strategies used by higher level students were more sophisticated, that is they used strategies involving manipulation rather than memorization and more interactive. Demirel (2012) found that as the level of language learning strategy use increased, student achievement increased as well. Also, this finding is supported by Oxford (1990, p.19) claiming that "learners who are more aware and more advanced seem to use better strategies" and by Chamot et al. (1987, p. 12) pointing out that "good language learners use a variety of strategies to assist them in gaining command over new language skills."

It should be noted that the correlation between language learning strategy use and achievement was low, as advocated by Park (2010). The researcher suggests several reasons for the law correlation between learning 
strategies and English proficiency such as the importance of the other variables which accounts for L2 proficiency except strategy use, the possibility of inaccurate SILL results, tasks not challenging enough for the effective learners to use specific strategies, effective learners automaticity in using learning strategies and failure in reporting subconscious strategies and also effective learners' use of strategies differently from ineffective learners in quality as well as quantity. It is thought that the most important reason of law correlation between strategy use and achievement in our study could be the inaccurate SILL results and negative effect of other variables which can be mostly affective such as self-efficacy, anxiety and motivation.

Also, it was found that among the six categories of language learning strategies only cognitive, compensation and metacognitive strategies were correlated with language achievement scores. It suggests that students with higher achievement scores used cognitive, compensation and metacognitive strategies more frequently than the students with lower achievement scores. However, mixed results have been reported in literature regarding the relationship between L2 performance and different categories of language learning strategies. For example, in a study by Bruen (2001) significant positive correlation were found between the number of cognitive and metacognitive strategies employed and levels of oral proficiency. Nisbet, Tindall, and Arroyo (2005) found that metacognitive strategies were significantly correlated with Institutional Testing Program (ITP-TOEFL) score and a combination of metacognitive strategies and affective strategies were significantly correlated with English proficiency. Goh and Foong (1997) found that proficiency level of the students had a significant influence on the use of cognitive and compensation strategies. In their study, Ketabi and Mohammadi (2012) significant correlations were reported between cognitive strategies and language proficiency. Tam (2013) found a positive correlation between compensation, cognitive and social strategies and L2 proficiency. Al-Qahtani (2013) reported that achievement in English was associated positively with social learning strategies. Magogwe and Oliver (2007) discovered that there was a significant interaction between proficiency and strategy categories at the primary school level but not at secondary or tertiary level. The authors concluded that higher proficiency level students at the primary school level used more social and metacognitive strategies compared to fair and poor proficiency students.

Perhaps the most surprising finding of the study was that students' gender did not indicate a statistically significant difference in terms of language learning strategy use except memory strategies. That is, only in terms of memory strategies, a statistically significant difference was found between the male and female students in favor of the female students. This finding is not supported by a considerable number of studies reporting that females use more language learning strategies than males (Demirel, 2012; Ehrman \& Oxford, 1988; Goh \& Foong, 1997; Green \& Oxford, 1995; Hong-Nam \& Leavell, 2006; Kayaoğlu, 2012; Kaylani, 1996; Oxford \& Nyikos, 1989). In a similar way, Božinovic and Sindik (2011) revealed that there were gender differences in the use of learning strategies, where the female sex more frequently used all types of learning strategies, apart from socio-affective strategies. In their study Hong-Nam and Leavell (2006) reported that females tended to use affective and social strategies more frequently than males. In a study by Tran (1988), men were reported to use various learning strategies to improve their language skills than the women. Furthermore, Oxford (1990, p.19) emphasizes that females use more and a large variety of language learning strategies compared to males. However, this finding is in contrast with those of Griffiths (2003), Nisbet et al. (2005) and El-Dib (1999 as cited in El-Dib, 2004, p. 93) who discovered that no statistically significant differences were found in reported frequency of language learning strategy use according to gender. As El-Dib (2004) articulates, the relationship between language learning strategy use and gender still remains unclear because of the cultural differences in raising children and education. The author suggests that the cultural environment and the opportunities provided for males and females might determine the strategy choice of either sex.

Another important finding of the present study was that metacognitive strategies were the most frequently used strategies among the students participating in the study, followed by compensation, social, memory, affective and cognitive strategies respectively. Our findings revealed that the students use all six types of strategies for learning English, although the frequency of using those strategies varies. Participants' greater use of metacognitive strategies such as centering, planning and evaluating learning can be explained by the fact that they were preparatory class students who were exposed to English a considerable amount of time (25 lesson-hours per week) and were busy with organizing, planning and evaluating their own language learning process. It was also seen that cognitive strategies were the least frequently used strategies by the students. It is a surprising finding because in several studies cognitive strategies have been reported as the most common strategies used by students at different levels of instruction (Chamot et al., 1987; Ghavamnia et al., 2011). Accordingly, Chamot (2004) points out, if students are learning a L2 in an academic context, it is important for them to develop cognitive strategies which will be helpful with language tasks. Also, Oxford (1990) 
acknowledges the importance of cognitive strategies by stating that "cognitive strategies are essential in learning a new language" (p. 43). So, it seems that students need training in language learning strategies, especially in cognitive strategies. As Chamot et al. (1987) indicate it is possible to train learners of English to use strategies for the tasks at hand and it is teachers' responsibility to help students apply learning strategies to different language activities and extend their strategy use. Therefore, it should not be forgotten that teaching learning strategies improves all four language skills (Allen, 2003). Participants' greater use of metacognitive strategies and limited use of cognitive strategies in this study indicates that they are engaged in regulating their own learning process rather than understanding and producing the language. This finding can be illuminated by O'Malley et al. (1987) explanation that metacognitive strategies can be applied to a wide variety of learning tasks, whereas cognitive strategies are limited to specific learning activities. Besides this, this finding can be clarified by the fact that use of cognitive strategies is more affected by the target language and level of instruction as pointed out by Chamot et al. (1987).

In the literature, different results have been reported about the frequency of language learning strategy use. Goh and Foong (1997) revealed that metacognitive strategies were used more frequently than the other types of strategy categories among Chinese students, while memory strategies were the least frequently used. Hong-Nam and Leavell (2006) found that the students preferred to use metacognitive strategies most, while affective and memory strategies were least preferred. The results of a study by Yllmaz (2010) showed that the highest rank was for compensation strategies while the lowest rank was for affective strategies. Ghavamnia et al. (2011) reported cognitive strategies as the most frequently used strategies while social strategies were the least frequently used ones. In a study by Božinovic and Sindik (2011) memory strategies were found to be the most frequently used ones, while cognitive strategies were the least frequently used. Demirel (2012) found that compensation strategies were the most frequent strategies while the memory strategies were the least frequently used strategies among the students. Magogwe and Oliver (2007) and Kunasaraphan (2015) concluded that metacognitive, social and cognitive strategies were more preferred than affective, memory and compensation strategies across all levels of education. These mixed results can be explained by the number of factors affecting language learning strategy use such as age, gender, nationality, learning style motivation level, learning stage and cultural differences (Oxford, 1990; Rubin, 1975). Also, when considered from a different viewpoint, frequently used strategies might be "culturally determined strategies" (Magogwe \& Oliver, 2007, p. 347). Different results in the literature can also be explained by El-Dib's (2004) assumption that "social context is probably the strongest variable influencing subjects to use certain strategies more than others" (p. 92). Participants' greater use of metacognitive strategies in this study can be regarded as a positive feature doe to the fact that, as suggested by Chamot et al. (1987), metacognitive strategies give students an opportunity to plan their learning process, monitor their learning and plan their future learning experiences. However, the authors note that application of newly learned strategies to new language tasks can be enhanced by matching metacognitive strategies with appropriate cognitive strategies. So it is believed that use of cognitive strategies should be enhanced through a specific instruction in language classes when necessary.

The data also revealed that students' use of affective strategies is very limited. This result is in line with several previous studies by Chamot and Kupper (1989), Chamot et al. (1987), Ghavamnia et al. (2011), Goh and Foong (1997), Magogwe and Oliver (2007). Participants' limited use of affective strategies could be attributed to their unawareness of the potential of affective strategies as explained by Magogwe and Oliver (2007). Moreover, participants' limited use of affective strategies can be illuminated by Oxford's (1990) explanation that these strategies are less frequently used compared to the other strategy categories although they are extremely useful for language learners having ordinary problems.

Moreover, it was found that the students had medium level strategy use in terms of total strategy use. Lack of high level strategy use can be attributed to the foreign language situation the students were in. As indicated by Green and Oxford (1995) in foreign language situations students have limited exposure to target language and limited communicative demand from the environment unlike the second language situation where students may have extensive exposure to the target language and a strong communicative demand from the environment. Regarding the level of strategy use, our findings are in line with those of Bekleyen (2006), Demirel (2012), Goh and Foong (1997), Kunasaraphan (2015) and Seffar (2014) who found that the university students had an average level of language learning strategy use. However, our findings are in contrast with those obtained by Hamamc1 (2012), who found that university preparatory class students had high level strategy use. Moreover, Deneme (2008) reported high use of compensation and metacognitive strategies and medium use of memory, cognitive, affective and social strategies among Turkish EFL students.

Finally, our findings have several implications for learning and teaching process. Based on the results and the 
related literature, it can be suggested that use of language learning strategies effectively can affect language learning in a positive way and increase achievement in language classes. Therefore, it is believed that strategy instruction in a L2 might have a positive impact on students" performance since "effective strategy use can be taught" (Green \& Oxford, 1995, p. 264). It is thought that identification of language learning strategies in L2 classrooms and making students aware of the wide range of language learning strategies that they can use to improve their learning in a L2 are of great significance in the effort to enhance language learning and teaching process. Chamot (2004) supports this idea by indicating that all the approaches to identify language learning strategies enhance students' metacognition about their own learning processes. It will also help students become more autonomous and self-regulated learners who can take their own responsibility for their own learning (Oxford, 1999). Therefore, foreign language teachers should be aware of the factors affecting students' strategy choice such as gender and proficiency level among others to help them consciously focus on their learning and become more strategic learners.

\section{Conclusion and Suggestions}

This study provides support for the presence of positive associations between language learning strategy use and foreign language achievement. Findings have demonstrated that only cognitive, compensation and metacognitive strategies were significantly correlated with foreign language achievement. Moreover, our results have shown that gender did not indicate any significant differences in preparatory class students' language learning strategy use except memory strategies. Also, it was discovered that metacognitive strategies were favored by the university preparatory class students, while use of cognitive and affective strategies was limited.

Based on the major findings of this study, the researchers have some suggestions for further research. First, since the participants comprised of the preparatory class students studying at only Necmettin Erbakan University School of Foreign Languages, generalization of the findings is limited. So, further research is, of course, required to investigate language learning strategy use of preparatory class students and the relationship between language learning strategies and achievement with larger sample size and in different educational settings. Second, data were collected via Turkish version of Strategy Inventory of Language Learning (SILL) which is a self-report questionnaire. As Chamot (2004) indicates self-report is accurate only if learners report truthfully. Therefore, diaries, journals, think-aloud individual interviews can also be used to collect information about learners' language learning strategy use. Third, as students' end-of-the-year scores were used as the achievement scores in this study, the researchers strongly recommend the use of a standardized proficiency test. In addition, further research is required to investigate any possible relationships between use of language learning strategies and other factors thought to affect strategy use and listed by Oxford (1990) such as degree of awareness, stage of learning, task requirements, teacher expectations, age, nationality, general learning style, personality traits, motivation level, and purpose for learning the language. This can allow language teachers to be aware of students' level of strategy use, support their strategy use by organizing materials and activities and modelling effective strategy use.

\section{References}

Allen, S. (2003). An analytic comparison of three models of reading strategy instruction. International Review of Applied Linguistics in Language Teaching, 41(4), 319-338. https://doi.org/10.1515/iral.2003.015

Al-Qahtani, M. F. (2003). Relationship between English language, learning strategies, attitudes, motivation, and students' academic achievement. Education in Medicine Journal, 5(3), 19-29. https://doi.org/10.5959/eimj.v5i3.124

Altan, M. Z. (2003). Language learning strategies and foreign language learning achievement. Education and Science, 28(129), 25-31. Retrieved from http://egitimvebilim.ted.org.tr/index.php/EB/article/view/5109/1193

Bekleyen, N. (2006). İngilizce öğretmen adaylarının dil öğrenme stratejileri kullanımı. Dil Dergisi, 132, 28-37. Retrieved from http://dergiler.ankara.edu.tr/dergiler/27/757/9634.pdf

Božinovic, N., \& Sindik, J. (2011). Gender differences in the use of learning strategies in adult foreign language learners. Methodological Horizons, 11(6), 5-20. Retrieved from http://hrcak.srce.hr/index.php?show=clanak\&id_clanak_jezik=106008

Bruen, J. (2001). Strategies for success: Profiling the effective learner of German. Foreign Language Annals, 34(3), 216-225. https://doi.org/10.1111/j.1944-9720.2001.tb02403.x

Cesur, M. O., \& Fer, S. (2007). What is the validity and reliability study of the Strategy Inventory of Language Learning?. Yüzüncü Yll Üniversitesi Ĕgitim Fakültesi Dergisi, 4(2), 49-74. Retrieved from 
http://efdergi.yyu.edu.tr/makaleler/cilt_IV/ii/mo_cesur.pdf

Chamot, A. U. (2004). Issues in language learning strategy research and teaching. Electronic Journal of Foreign Language Teaching, 1(1), 14-26. Retrieved from http://e-flt.nus.edu.sg/v1n12004/chamot.pdf

Chamot, A. U., \& El-Dinary, P. B. (1999). Children's learning strategies in language immersion classrooms. The Modern Language Journal, 83(3), 319-338. https://doi.org/10.1111/0026-7902.00025

Chamot, A. U., \& Kupper, L. (1989). Learning strategies in foreign language instruction. Foreign Language Annals, 22, 13-24. https://doi.org/10.1111/j.1944-9720.1989.tb03138.x

Chamot, A. U., O’Malley, J. M., Kupper, L., \& Impink-Hernandez, M. V. (1987, January). A study of Learning strategies in foreign language instruction. First year report. Retrieved from http://files.eric.ed.gov/fulltext/ED352824.pdf

Chang, C., \& Liu, H. (2013). Language learning strategy use and language learning motivation of Taiwanese EFL university students. Electronic Journal of Foreign Language Teaching, 10(2), 196-209. Retrieved from http://e-flt.nus.edu.sg/v10n22013/chang.pdf

Demirel, M. (2012). Language learning strategies of undergraduate students. Hacettepe University Journal of Education, 43, 141-153. Retrieved from http://til.nccu.edu.tw/volume11-2/11.2.1.pdf

Deneme, S. (2008). Language learning strategy preferences of Turkish students. Journal of Language and Linguistic Studies, 4(2), 83-93. Retrieved from http://www.jlls.org/index.php/jlls/article/view/68/68

Ehrman, M., \& Oxford, R. (1988). Effects of sex differences, career choice, and psychological type on adult language learning strategies. Modern Language Journal, 72(3), 253-265. https://doi.org/10.2307/327503

El-Dib, M. A. B. (2004). Language learning strategies in Kuwait: Links to gender, language level, and culture in a hybrid context. Foreign Language Annals, 37(1), 85-95. https://doi.org/10.1111/j.1944-9720.2004.tb02176.x

Fewell, N. (2010). Language learning strategies and English language proficiency: an investigation of Japanese EFL university students. TESOL Journal, 2, 159-174. Retrieved from http://tesol-international-journal.com/wp-content/uploads/2013/11/A11V2_TESOL.pdf

Ghavamnia, M., Kassaian, Z., \& Dabaghi, A. (2011). The relationship between language learning strategies, language learning beliefs, motivation, and proficiency: A study of EFL learners in Iran. Journal of Language Teaching and Research, 2(5), 1156-1161. https://doi.org/10.4304/jltr.2.5.1156-1161

Goh, C. C., \& Foong, K. P. (1997). Chinese ESL students' learning strategies: A look at frequency, proficiency, and gender. Hong Kong Journal of Applied Linguistics, 2(1), 39-53. Retrieved from http://www2.caes.hku.hk/hkjal/issue/back-issues/hkjal-vol-2-1/

Green, J. M., \& Oxford, R. L. (1995). A closer look at learning strategies, L2 proficiency, and gender. Tesol Quarterly, 29 (2), 261-297. https://doi.org/10.2307/3587625

Griffiths, C. (2003). Patterns of language learning strategy use. System, 31, 367-383. https://doi.org/10.1016/S0346-251X(03)00048-4

Griffiths, C., \& Oxford, R. L. (2014). The twenty-first century landscape of language learning strategies: Introduction to this special issue. System, 43, 1-10. https://doi.org/10.1016/j.system.2013.12.009

Griffiths, C., Rebecca, L. O., Kawai, Y., Kawai, C., Park, Y. Y., Ma, X., ... Yang, N-d. (2014). Focus on context: Narratives from East Asia. System, 43, 50-63. https://doi.org/10.1016/j.system.2013.12.013

Hamamcı, Z. (2012). Üniversite hazırlık sınıfı öğrencilerinin dil öğrenme strateji tercihleri. Eğgitim ve Öğretim Araştırmalarl Dergisi, $\quad$ 1(3), 314-323. $\quad$ Retrieved from http://www.jret.org/FileUpload/ks281142/File/33z.hamamci.pdf

Hong-Nam, K., \& Leavell, A. G. (2006). Language learning strategy use of ESL students in an intensive English learning context. System, 34, 399-415. https://doi.org/10.1016/j.system.2006.02.002

Hsiao, T.-Y., \& Oxford, R. L. (2002). Comparing theories of language learning strategies: A confirmatory factor analysis. The Modern Language Journal, 86(3), 368-383. https://doi.org/10.1111/1540-4781.00155

Karasar, N. (2005). Bilimsel araştırma yöntemi (14th ed.). Ankara: Nobel Yayın Dağıtım.

Kayaoğlu, M. N. (2012). Gender based differences in language learning strategies of science students. Journal of Turkish Science Education, 9(2), 12-24. $\quad$ Retrieved from 
http://uvt.ulakbim.gov.tr/uvt/index.php?cwid=9\&vtadi=TSOS\&c=ebsco\&ano=150945_4bb2da25a77b36fea $72924 \mathrm{~b} 18 \mathrm{~d} 7 \mathrm{fa} 240 \&$ ?

Kaylani, C. (1996). The influence of gender and motivation on EFL learning strategy use in Jordan. In R. Oxford (Ed.), Language learning strategies around the world: Cross-cultural perspectives (pp. 75-88). Honolulu, HI: University of Hawaii Press.

Ketabi, S., \& Mohammadi, A. M. (2012). Can learning strategies predict language proficiency? A case in Iranian EFL context. International Journal of Linguistics, 4(4), 407-418. https://doi.org/10.5296/ijl.v4i4.2914

Kunasaraphan, K. (2015). English learning strategy and proficiency level of the first year students. Procedia Social and Behavioral Sciences, 197, 1853-1858. https://doi.org/10.1016/j.sbspro.2015.07.246

Magogwe, J. M., Oliver, R. (2007). The relationship between language learning strategies, proficiency, age and self-efficacy beliefs: A study of language learners in Botswana. System, 35, 338-352. https://doi.org/10.1016/j.system.2007.01.003

Nisbet, D. L., Tindall E. R., \& Arroyo, A. A. (2005). Language learning strategies and English proficiency of Chinese university students. Foreign Language Annals, 38(1), 100-107. https://doi.org/10.1111/j.1944-9720.2005.tb02457.x

O’Malley, J. M., Chamot, A. U., \& Kupper, L. (1987, June). The role of learning strategies in second language acquisition: Strategy use by students of English. Retrieved from http://www.dtic.mil/dtic/tr/fulltext/u2/a192006.pdf

Oxford, R. L. (1989). The role of styles and strategies in second language learning. Retrieved from http://files.eric.ed.gov/fulltext/ED317087.pdf

Oxford, R. L. (1990). Language learning strategies: What every teacher should know. Boston, MA: Heinle \& Heinle.

Oxford, R. L. (1999). Relationships between second language learning strategies and language proficiency in the context of learner autonomy and self-regulation. Revista Canaria de Estudios Ingleses, 38, 109-126.

Oxford, R. L., \& Burry-Stock, J. A. (1995). Assessing the use of language learning strategies worldwide with the Esl/Efl version of the strategy inventory for language learning (SILL). System, 23(1), 1-23. https://doi.org/10.1016/0346-251X(94)00047-A

Oxford, R., \& Nyikos, M. (1989). Variables affecting choice of language learning strategies by university $\begin{array}{lllll}\text { students. } & \text { The }\end{array}$ https://doi.org/10.1111/j.1540-4781.1989.tb06367.x

Park, G.-P. (2010). Investigation into learning strategies used by effective and less effective EFL learners in Korea. Asian Social Science, 6(8), 3-13. http://dx.doi.org/10.5539/ass.v6n8p3

Qingquan, N., Chatupote, M., \& Teo, A. (2008). A deep look into learning strategy use by successful and unsuccessful students in the Chinese EFL learning context. RELC Journal, 39, 338-358. https://doi.org/10.1177/0033688208096845

Rubin, J. (1981). Study of cognitive processes in second language learning. Applied Linguistics, 11, 117-131. https://doi.org/10.1093/applin/II.2.117

Seffar, S. (2014). An exploratory study of vocabulary learning strategies of Moroccan University students. Journal of Research and Method in Education, 4(2), 38-45. Retrieved from http://www.iosrjournals.org/iosr-jrme/papers/Vol-4\%20Issue-2/Version-2/H04223845.pdf

Tam, K. C. H. (2013). A study on language learning strategies (LLSs) of University students in Hong Kong. Taiwan Journal of Linguistics, 11(2), 1-42. https://doi.org/10.6519/TJL.2013.11(2).1

Tran, T. V. (1988). Sex differences in English language acculturation and learning strategies among Vietnamese adults aged 40 and over in the United States. Sex Roles, 19(11/12), 747-758. https://doi.org/10.1007/BF00288990 


\section{Copyrights}

Copyright for this article is retained by the author(s), with first publication rights granted to the journal.

This is an open-access article distributed under the terms and conditions of the Creative Commons Attribution license (http://creativecommons.org/licenses/by/4.0/). 